\title{
Mercury in Eledone cirrhosa from the Northern Tyrrhenian Sea: contents and relations with life cycle
}

\author{
A. ROSSI*, D. PELLEGRINI $\dagger$, P. BELCARI $\ddagger$ and C. BARGHIGIANI* \\ *Istituto di Biofisica (C.N.R.), Via S. Lorenzo 26, 56100 Pisa, Italy \\ $\dagger$ Istituto Centrale per la Ricerca Scientifica e Tecnologica Applicata al Mare (ICRAM), Via L. Respighi 5, o0196, \\ Rome, Italy \\ $\ddagger$ Dipartimento di Scienze dell'Ambiente e del Territorio, Università di Pisa, Via Volta, 56100 Pisa, Italy
}

\begin{abstract}
The Hg concentration in horned octopus was studied in relation to its biological cycle. The metal was measured in the muscle tissue of specimens of different size, sex and maturity. This species proved to be a strong accumulator of mercury, whose concentration was found to be correlated with length independently of the sex. The relationship with size was found also for the organic form. Consideration was given to the danger of frequent consumption of this cephalopod and to its use as a biomonitor of environmental mercury impact.
\end{abstract}

It has long been known that the ecosystem of the Northern Tyrrhenian Sea is contaminated by $\mathrm{Hg}$ due to the cinnabar anomaly of Mt Amiata (Tuscany) and the related mercury extraction activities carried out there for many centuries.

High mercury concentrations have been reported in sediment (Baldi et al., 1979; Barghigiani et al., 1986) as well as in important edible fish, crustaceans and molluscs (Renzoni \& Baldi, 1975; Barghigiani et al., 1991; Barghigiani et al., 1992). In all the organisms studied the mercury concentration in muscle tissue increased with the size, varied depending on the species, and in the same species showed variation with depth (Barghigiani et al., 1986). It has also been reported that the different mercury concentrations of similar species of flatfish were probably due to the structure of the corresponding trophic chains (Pellegrini \& Barghigiani, 1989). In fish of other geographic regions, differences of accumulation were found between the two sexes (Monteiro \& Lopes, 1990; Monteiro et al., 1991) and among the different organs (Hornung \& Cohen, 1986), depending on the environment (Luten et al., 1987).

From this evidence, it appears that information on $\mathrm{Hg}$ accumulation in marine organisms is wide but fragmentary and mainly addresses fish and crustaceans. Considerably less information exists on this topic for cephalopods, even though they play important roles both in the marine ecosystem and in the human diet (Amaratunga, 1983).

The present investigation is directed at the study of mercury uptake and concentration in the muscle tissue of the horned octopus, Eledone cirrhosa (Lamarck 1798, Cephalopoda, Octopoda), in the Northern Tyrrhenian Sea. This species, occurring from the western basin of the Mediterranean to the North Sea, is truly benthic, living at a wide range of depths (Mangold \& Boletzky, 1987). Mangold et al. (1971) refer to it as "probably the most abundant cephalopod of the northwestern Mediterranean". Seasonal minimum stock biomass estimates for the whole Tyrrhenian Sea show that the highest production occurs in the study area (Würtz et al., 1992), where Eledone cirrhosa represents the largest catch among celphalopds (Belcari et al., 1986; Belcari \& Sartor, in press).

Eledone cirrhosa stops growing with the attainment of sexual maturity and after spawning it disappears from the fishery area, probably dying (Mangold-Wirz, 1963; Boyle, 1983).

It is possible to suggest a complete life cycle for this species in the Northern Tyrrhenian Sea that never exceeds two years, with a maturation period in the second year of life in the months of June, July and August (Belcari et al., 1990). In this area the species is found from 5 to $630 \mathrm{~m}$ depth and sizes range from $1.5 \mathrm{~cm}$ to $14.5 \mathrm{~cm}$ mantle length (Belcari \& Sartor, in press), in agreement with data reported for the other areas of the Mediterranean Sea (Mangold \& Boletzky, 1987).

Since this is one of the most widespread and most consumed molluscs of the Tyrrhenian Sea and its cycle is brief and known, it has been studied with the aim of giving an evaluation of its possible impact on human health and gaining information on its use for the biological monitoring of mercury contamination in the Mediterranean.

\section{Materials and Methods}

The specimens were collected during eighteen 


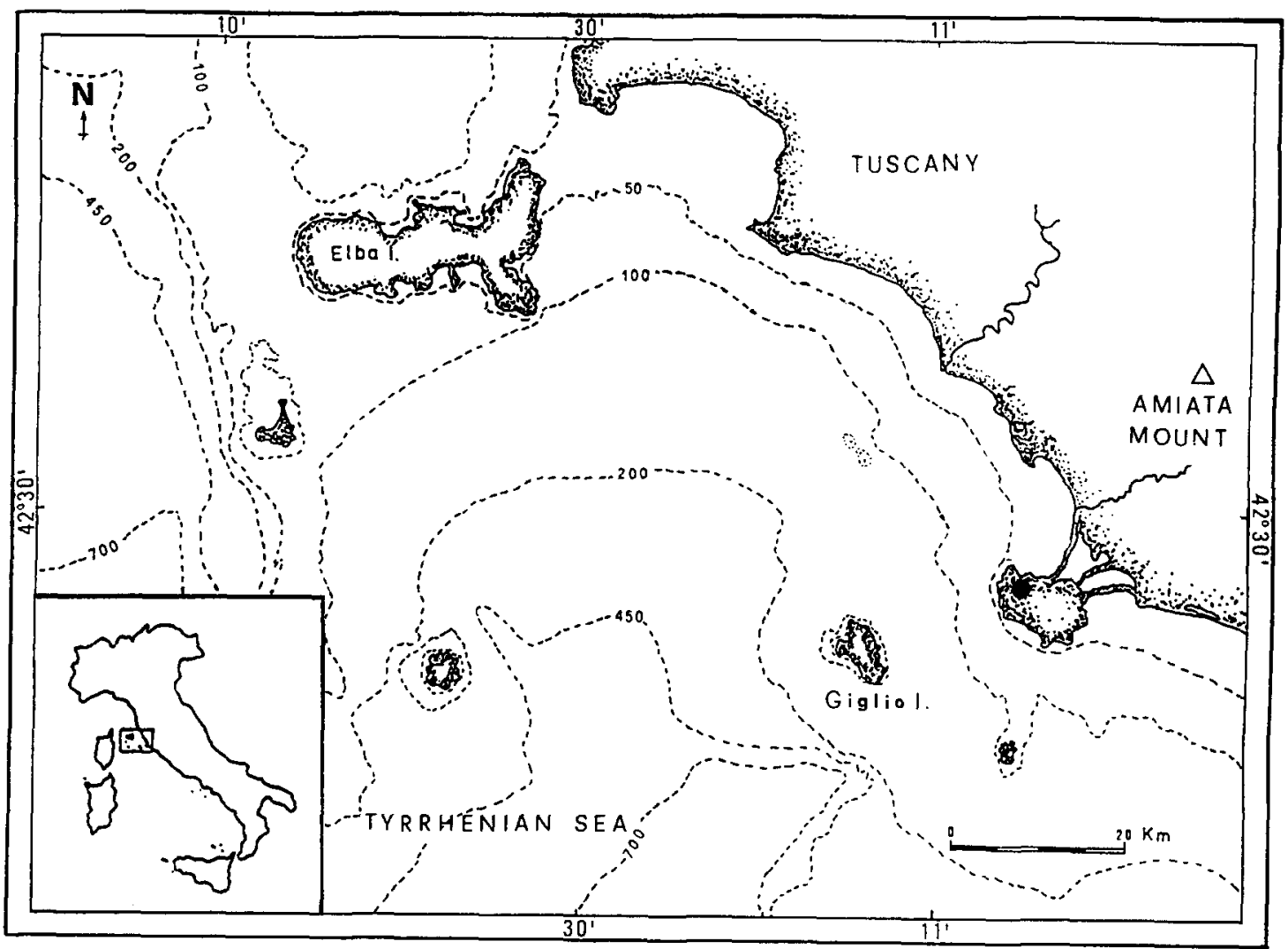

Fig. 1 Study area.

monthly samplings from March 1989 to August 1990 in the study area of the Northern Tyrrhenian Sea reported in Fig. 1, between 52 and $350 \mathrm{~m}$ depth, with the greatest abundance between 100 and $130 \mathrm{~m}$.

Every specimen was weighed, measured as dorsal mantle length and sexed. The state of maturity of the gonads was assessed on the criteria of relative size, colour and appearance of the eggs and spermatophores, according to Mangold \& Wirz (1963), Sanchez (1976) and Moriyasu (1981). The sizes ranged from 3.5 to $13.5 \mathrm{~cm}$ mantle length (ML).

From the analysis of size-frequency histograms of the field catch (Bhattacharia, 1967) and observation of the maturity stages (Fedi, 1988; Belcari et al., 1990), it was possible to single out a cohort to be followed every month from the juvenile stages to the completely mature stages.

Total and methylmercury analyses were performed on mantle muscle tissue of 142 specimens. Total mercury was determined by cold vapour atomic absorption spectrometry (CVAAS) on samples digested with nitric acid in a closed system under pressure as reported elsewhere (Barghigiani et al., 1986). Organic mercury was determined by CVAAS after extraction from samples according to Capelli et al. (1979) and mineralization in a closed system as performed for total mercury.

The analytical procedures were tested using Certified Reference Materials DORM-1 (dogfish muscle) of the National Research Council of Canada.

\section{Results and Discussion}

Despite its short life cycle, Eledone cirrhosa accumu-

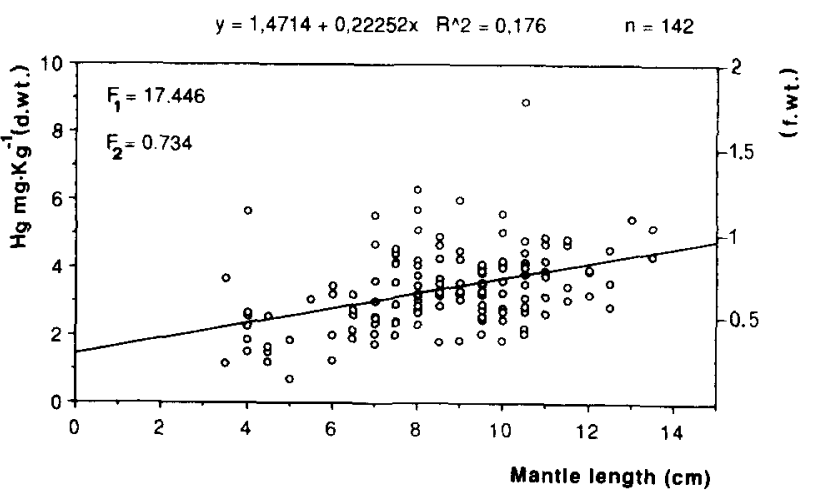

Fig. 2 Relationship between total mercury concentration (expressed as dry and fresh wt) and mantle length in all the specimens analysed.

lated high levels of mercury (Fig. 2) and from the size limit of $6 \mathrm{~cm}$ of mantle length upwards, $50 \%$ of specimens exceeded the maximum concentration of total $\mathrm{Hg}(0.7 \mu \mathrm{g} / \mathrm{g}$ of fresh wt) set by Italian law for those species of edible marine organisms considered mercury concentrators, i.e. bivalve molluscs, sharks, smooth-hounds and dog-fish (FAO, 1983).

Mercury accumulation increased with size, as indicated by Fig. 2. This relationship was not observed earlier on a smaller sample of the same species collected without regard to its biological cycle (Barghigiani et al., 1991). The relationship between $\mathrm{Hg}$ concentration and mantle length in females and males (Figs 3, 4) was significant. The linearity of the regression $\left(F_{2}=0.932, p>0.005\right.$ for females; $F_{2}=0.526$, $p>0.005$ for males) and the significance of the regression $\left(F_{1}=9.175, \quad p>0.005\right.$ for females; $F_{1}=10.518, p>0.005$ for males) were tested. On the 


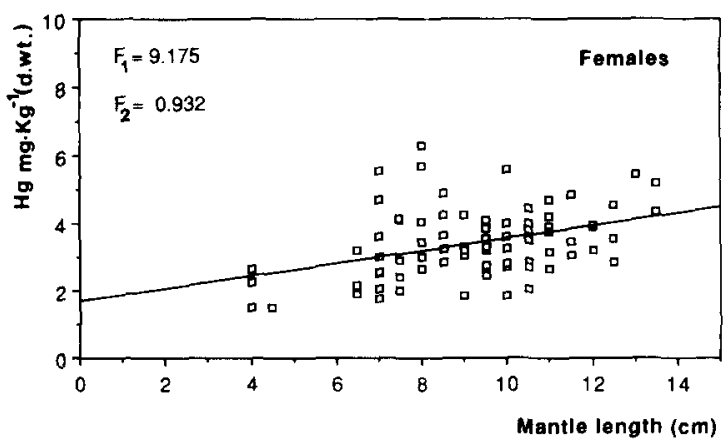

Fig. 3 Relationship between total mercury concentration (dry wt) and mantle length in females.

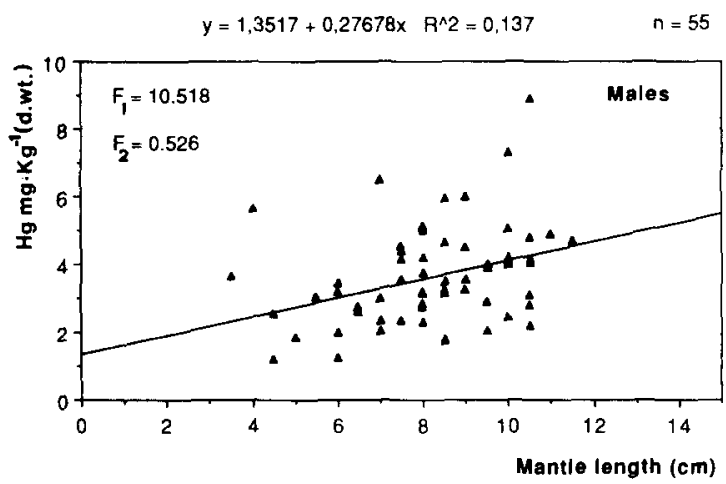

Fig. 4 Relationship between total mercury concentration (dry wt) and mantle length in males.

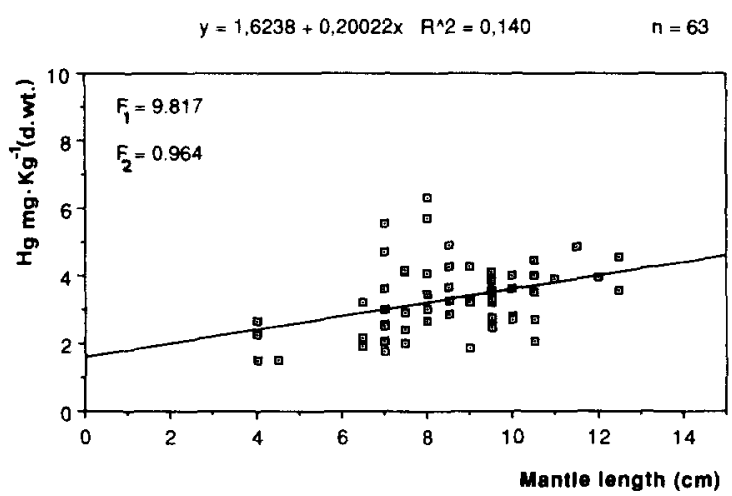

Fig. 5 Relationship between total mercury concentration (dry wt) and mantle length in immature females.

contrary, no significant difference was found between both the slopes $(t=0.500, p>0.001)$ and the intercepts $(t=1.980, p>0.001)$ of the two regresion lines, indicating no difference in $\mathrm{Hg}$ accumulation between the two sexes. In other species (Pontinus khulii, Galeorhinus australis, Mustelus antarticus, Nephrops norvegicus), however, different $\mathrm{Hg}$ contents have been observed between the two sexes (Monteiro et al., 1991; Walker, 1976; Minganti et al., 1980).

In immature females (Fig. 5) the relationship between $\mathrm{Hg}$ and size was significant $\left(\mathrm{F}_{2}=0.964, \mathrm{p}>0.005\right.$; $F_{1}=9.817, p>0.005$ ); conversely, this was not observed in the few mature and maturing females $\left(F_{2}=0.557\right.$, $p>0.005 ; F_{1}=2.636, p>0.005$ ) (Fig. 6). The analyses of the maturing and mature females suggest a reduction in the mercury uptake near spawning. This phenomenon could be due to a variation in the diet or a decrease in feeding; indeed, many octopodid females

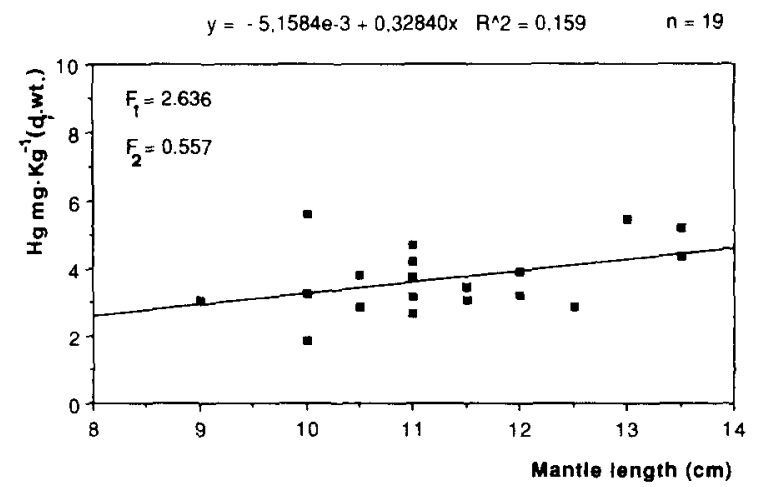

Fig. 6 Relationship between total mercury concentration (dry wt) and mantle length in mature females.

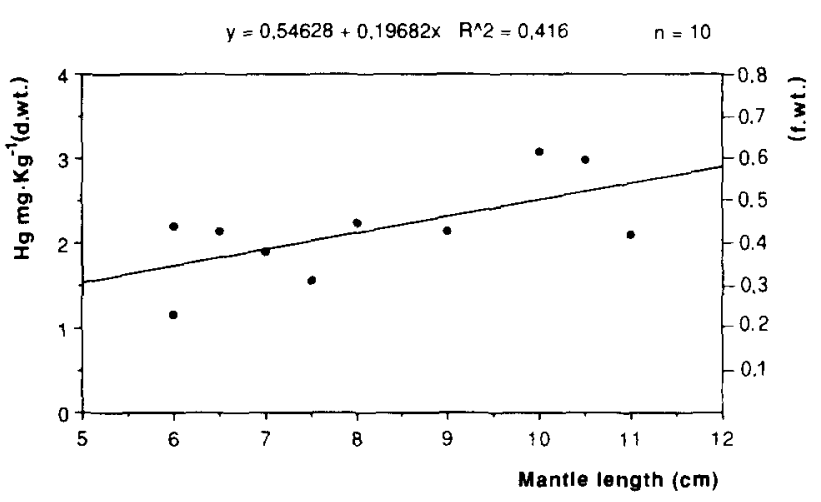

Fig. 7 Relationship between organic mercury content (expressed as dry and fresh wt) and mantle length.

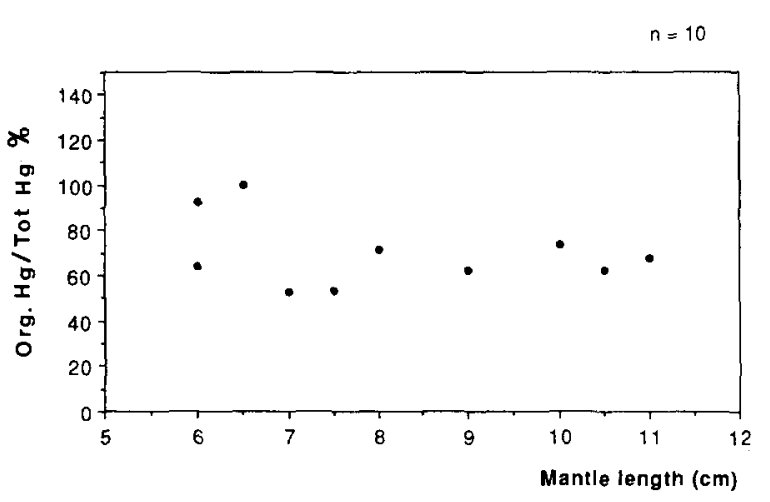

Fig. 8 Organic mercury as a percentage of total mercury vs. mantle length.

near spawning are known to feed less or terminate ingestion altogether (Mangold, 1983). On the contrary, in female fish and crustacean species (Nicoletto \& Hendricks, 1987; Minganti et al., 1990), an increase in $\mathrm{Hg}$ concentration vs. size was observed with the acquisition of sexual maturity.

In the present study organic mercury increased with length (Fig. 7) and as a percentage of the total $\mathrm{Hg}$ it remained constant (Fig. 8). In other species from the nearby Ligurian Sea organic mercury increased with size more than did inorganic mercury (Capelli et al., 1987; Minganti et al., 1990), and a linear correlation with the total $\mathrm{Hg}$ existed for organic mercury only (Minganti et al., 1990).

It is notable that the average organic mercury percentage with respect to the total (70 15 S.D.) was found to be lower than that of some species of fish from the same area ( $84 \pm 9$ S.D.) (Barghigiani et al., 1991). 


\section{Conclusions}

Eledone cirrhosa proved to be a strong accumulator of mercury, and most of the specimens caught presented high mercury levels.

It is important to point out that no mercury concentration limits are provided by Italian law for Eledone cirrhosa. Thus, this organism, which frequently enters into the diet of people living along the Northern Tyrrhenian Sea, is not controlled and could be detrimental to their health. Indeed, from our data, a weekly consumption of $500 \mathrm{~g}$ of muscle tissue of this cephalopod would result in the average intake of 200 $\mu \mathrm{g}$ of methylmercury, which is the maximum limit per week indicated by FAO/WHO (1980) for a person weighing $60 \mathrm{~kg}$.

From the environmental point of view, since this species is characterized by fast growth and a short life cycle which does not exceed two years, it could be usefully employed as a biomonitor of environmental mercury for comparing both the levels of the metal in different areas and especially the variations in the same area between different periods. It is important to note that due to the high variability of $\mathrm{Hg}$ concentration in specimens of the same size, effective biological monitoring of the mercury requires the analysis of a large number of specimens collected over the entire life cycle.

Amaratunga, T. (1983). The role of cephalopods in the marine ecosystem. In Advances in Assessment of World Cephalopod Resources. (I. F. Caddy, ed.), FAO FISH. Tech. Pap. 231, 379-415.

Baldi, F., Bargagli, R. \& Renzoni, A. (1979). The distribution of mercury in the surficial sediments of the Northern Tyrrhenian Sea. Mar. Pollut. Bull. 10, 301-303.

Barghigiani, C., Pellegrini, D., Gioffrè, D., De Ranieri, S. \& Bargagli, R. (1986). Preliminary results on the mercury content of Citharus linguatula (L.) in the Northern Tyrrhenian Sea. Mar. Pollut. Bull. 17, $424-427$

Barghigiani, C., Pellegrini, D., D’Ulivo, A. \& De Ranieri, S. (1991). Mercury assessment and its relation to selenium levels in edible species of the Northern Tyrrhenian Sea. Mar. Pollut. Bull. 22, 406409 .

Barghigiani, C. \& De Ranieri, S. (1992). Mercury content in different size classes of important edible species of the Northern Tyrrhenian Sea. Mar. Pollut. Bull. 24, 114-116.

Belcari, P., Biagi, F., Biagi, V., De Ranieri, S., Mori, M. \& Pellegrini, D. (1986). Observation about cephalopod distribution in the Northern Tyrrhenian Sea. Rapp. Comm. Int. Mer. Médit. 30, (2), 246.

Belcari, P., Fedi, E. \& Sartor, P. (1990). Analysis of the sexual development of Eledone cirrhosa (Cephalopoda, Octopoda) in the Northern Tyrrhenian Sea through two maturity indices. Rapp. Comm. Int. Mer Médit. 32, 1, 241.

Belcari, P. \& Sartor, P. Trawling bottom teutophauna of the Northern Tyrrhenian Sea. Scientia marina (in press).

Bhattacharia, C. G. (1967). A simple method of resolution of a distribution into Gaussian components. Biometrics 23, 115-131.
Boyle, P. R. (1983). Eledone cirrhosa. In: P. R. Boyle (ed.). (ephalopod Life Cycles 1, 365-386.

Buffoni, G., Bernhard, M. \& Renzoni, A. (1982). Mercury in the Mediterranean tuna. Why is their level higher than in Atlantic tuna? A model. Thalass. Yugosl. 18, 231-243.

Capelli, R.. Fezia, C.. Franchi, A. \& Zanicchi, G. (1979). Extraction of methylmercury from fish and its determination by atomic-absorption spectroscopy. Short papers, Analyst 104, 1197-1200.

Capelli, R., Minganti, V. \& Bernhard, M. (1987). Total mercury, organic mercury, copper, manganese, selenium, and zinc in Sarda sarda from the Gulf of Genoa. Sci. Total Environ. 63.8.3-99.

FAO (1983). FAO Fisheries Circular No. 764. October 1983.

Fedi, E. (1988). Biologia riproduttiva e distribuzione di Eledone cirrhosa (Lamarck 1798) nel mar Tirreno Settentrionale. Tesi di laurea. Università degli Studi di Pisa.

Hornung, H. \& Cohen, Y. (1986). Accumulation of mercury and its distribution in various organs of the white bream Diplodus sargus. Rapp. Comm. Int. Mer. Médit. 30 (2), 116

Luten, J. B., Bouquet, W., Riekwel-Booy, G., Rauchbaar, A. B. \& Scholte, M. W. M. (1987). Mercury in flounder, Platichtys flesus, cod Gadus morhua, and perch, Perca fluviatilis, in relation to their length and environment. Bull. Environm. Contam. Toxicol. 38, 318-323.

Mangold, K. \& Boletzky, S. V. (1987). Céphalopodes. In: Fishes FAO d'identifications des espèces pour les besoins de la pêche. (Révision 1). Méditerranée et Mer Noire. Zone de peche 37. Fisher W. Bauchot, M. L. \& Scheider, M. (rédacteurs). Volume l. Végétaux et Invertébrés, FAO, Rome: 633-714.

Mangold, K., Boletzky, S. V. \& Froesh, D. (1971). Reproductive biology and embryonic development of Eledone cirrhosa (Cephalopoda Octopoda). Mar. Biol. 8 (2), 109-117.

Mangold-Wirz, K. (1963). Biologie des Céphalopodes benthiques et nectoniques de la Mer Catalane. Vie Milieu, 13 (suppl.), 285 pp

Mangold, K. (1983). Food, feeding and growth in Cephalopods. Mem Natl. Mus. Victoria 44, 81-93.

Minganti, V., Capelli, R. \& De Pellegrini, R. (1990). The presence of inorganic and organic mercury and selenium in Nephrops norvegicus from the Ligurian Sea. Sci. Total Environ. 95, 53-60.

Monteiro, L. R. \& Lopes, H. D. (1990), Mercury content in swordfish, Xiphias gladius, in relation to length, weight, age and sex. Mar. Pollut Bull. 21, 293-296.

Monteiro, L. R., Isidro. E. J. \& Lopes, H. D. (1991). Mercury content in relation to sex, size, age and growth in two species of scorpionfish (Helicolenus dacylopterus and Pontinus khulii) from Azorean waters. Water Air and Soil Pollut. 56, 359-367

Moriyasu. M. (1981). Biologie des pèches de céphalopodes benthiques. Application aux Eledones; Eledone cirrhosa (Lam. 1798) du Golf du Lion. Thèse doctorat, 3ème cycle. Université des Sciences et Technique du Languedoc, Montpellier, France.

Nicoletto, .P. F. \& Hendricks, A. C. (1987). Sexual differences in accumulation of mercury in four species of centrarchid fishes. Can. $J$ Zool. 66, 944-949.

Pellegrini, D. \& Barghigiani, C. (1989). Feeding behaviour and mercury content in two flat fish in the Northern Tyrrhenian Sea. Mar. Pollut. Bull. 20, 443-447.

Renzoni, A. \& Baldi, F. (1975). Osservazioni sulla distribuzione di mercurio nella fauna del Mar Ligure e del Mar Tirreno. Acqua + Aria $8,597-602$.

Sanchez, P. (1976). Contribución al estudio de la maduración sexual de Eledone cirrhosa (Lamarck). Tesis. Universidad de Barcelona. España.

Walker, T. I. (1976). Effects of species, sex, length, and locality on the mercury content of school shark Galeorhinus australis (Macleay) and gummy shark Mustelus antarticus (Guenther) from South-eastern Australian waters. Aust. J. Mar. Freshw. Res. 27, 603-616.

WHO (1980). Report on consultation to re-examine the WHO environmental health criteria for mercury. Genova. April 21-25. 1980.

Wurtz, M., Matricardi, G. \& Belcari, P. (1992). Distribution and abundance of the octopus Eledone cirrhosa in the Northern Tyrrhenian Sea, Central Mediterranean. Fish Res. 13 (1), 53-66. 